\title{
Effects of Prophylactic Thyroid Hormone Replacement in Euthyroid Hashimoto's Thyroiditis
}

\author{
DUYGU YAZGAN AKSOY, ULKU KERIMOGLU*, HAMZA OKUR**, HANDE CANPINAR***, \\ ERGUN KARAAĞAOĞLU", SEVGI YETGIN**, EMIN KANSU"\# AND OLCAY GEDIK
}

\author{
Section of Endocrinology and Metabolism, Department of Internal Medicine, Hacettepe University, 06100 Sihhiye, Ankara, Turkey \\ *Department of Radiology, Hacettepe University, 06100 Sihhiye, Ankara, Turkey \\ **Section of Hematology, Department of Pediatrics, Hacettepe University, 06100 Sihhiye, Ankara, Turkey \\ ***Department of Basic Oncology, Institute of Oncology, Hacettepe University, 06100 Sihhiye, Ankara, Turkey \\ \#Department of Biostatistics, Hacettepe University, 06100 Sihhiye, Ankara, Turkey \\ \#Department of Internal Medicine, Hacettepe University, Section of Oncology, 06100 Sihhiye, Ankara, Turkey
}

\begin{abstract}
Hashimoto's thyroiditis is the most frequent autoimmune thyroid disease. L-thyroxine therapy can reduce the incidence and alleviate the symptoms of this disease. The aim of this study was to evaluate the effects of prophylactic Lthyroxine treatment on clinical and laboratory findings of patients who were euthyroid at the time of diagnosis. Thirtythree patients who had diagnosis of euthyroid Hashimoto's thyroiditis were randomized to two groups, one group received prophylactic L-thyroxine treatment and the other was followed-up without treatment. Initial thyroid function tests, autoantibodies, ultrasonography, fine needle aspiration biopsy and peripheral blood lymphocyte subsets were similar in the two study groups. After 15 months of L-thyroxine treatment, there was a significant increase in free $\mathrm{T}_{4}$ and a significant decrease in TSH and anti-thyroglobulin antibody anti-thyroid peroxidase antibody levels. $\mathrm{CD} 8^{+}$cell counts increased in both groups, CD4/CD8 levels decreased significantly because of the increase in CD8 ${ }^{+}$cell count levels. Though there was no change in cytological findings, ultrasonography showed a decrease in thyroid volume in L-thyroxine receiving patients whereas an increase was detected in patients who were followed without treatment. In conclusion, prophylactic thyroid hormone therapy can be used in patients with Hashimoto's thyroiditis even if they are euthyroid.
\end{abstract}

Key words: Hashimoto's thyroiditis, Euthyroid, Autoantibodies, Lymphocyte subpopulations

(Endocrine Journal 52: 337-343, 2005)

HASHIMOTO'S thyroiditis is the most common autoimmune thyroid disorder characterized by diffuse lymphocytic infiltration, lymphoid follicule formation, epithelial cell destruction, fibrous tissue proliferation and presence of thyroid autoantibodies [1-3].

In Hashimoto's thyroiditis the anti-thyroid immune response begins with the activation of the thyroid antigen-specific helper $\mathrm{T}$ cells and once they are activated, they induce B cells to secrete thyroid antibodies [4]. The mechanism for autoimmune destruction of the

Received: August 9, 2004

Accepted: February 24, 2005

Correspondence to: Duygu Yazgan AKSOY M.D., Department of Internal Medicine, Hacettepe University, 06100 Sihhiye, Ankara, Turkey thyroid probably involves both cellular immunity and humoral immunity. Lymphocytic infiltration of the thyroid gland by equal number of B cells and cytotoxic $\mathrm{T}$ cells is a common histologic feature [4]. Studies evaluating peripheral and intrathyroidal lymphocytic populations from these patients revealed different results [5-8]. The effect of L-thyroxine $\left(\mathrm{LT}_{4}\right)$, which has been proven to modulate the immune process in animal models of spontaneous lymphocytic thyroditis animal models, is not clear when it comes to clinical studies especially for euthyroid patients for whom $\mathrm{LT}_{4}$ therapy indication is controversial [9-13]. Different effects on serum thyroid autoantibodies, peripheral and intrathyroidal lymphocytes have been reported [14-22]. The aim of this clinical study was to investigate the influence of prophylactic $\mathrm{LT}_{4}$ therapy on thyroid auto- 
antibodies, goiter size, cytological findings and peripheral lymphocyte populations in euthyroid patients with Hashimoto's thyroiditis.

\section{Material and Methods}

\section{Patients}

Between January 2001-December 2002, 33 patients (32 female, 1 male, ages between 21-52, mean $38.83 \pm 9.61)$ with Hashimoto's thyroiditis were included in the study. All patients were euthyroid (the patients' thyroid hormone measurements made on two consecutive visits; two patients had low free $\mathrm{T}_{4}$ but normal free $\mathrm{T}_{3}$ and TSH levels at first visit; all their hormone levels were within normal range on the second measurement but the first measured levels were used for statistical analysis), free of symptoms and/or ECG findings of coronary heart disease, none had systemic illness (including renal, pulmonary, liver diseases and osteoporosis) or history of synthetic thyroid hormone therapy during the last ten years. After obtaining written informed consent, 17 patients were randomised to follow up without treatment (Group1) while the rest of them were put on $\mathrm{LT}_{4}$ (Group 2). The diagnosis of Hashimoto's thyroiditis was based on ultrasonography (volume), laboratory criteria [thyroid stimulating hormone (TSH), free triiodothyronine $\left(\mathrm{FT}_{3}\right)$, free thyroxine $\left(\mathrm{FT}_{4}\right)$, anti-thyroglobulin $(\mathrm{Tg}-\mathrm{Ab})$ and anti-thyroid peroxidase (TPO-Ab) antibodies] and cytology obtained by fine needle aspiration biopsy (FNAB). After 12 hours of fasting, between 8.30 and 10.30 a.m. blood samples were obtained for complete blood count and lymphocyte subpopulations. $\mathrm{LT}_{4}$ therapy was initiated in Group 2 with a dose of $50 \mu \mathrm{g}$ of $\mathrm{LT}_{4}$ per day. Serum TSH levels were checked one month after treatment and maintenance dose was adjusted so that serum TSH levels were kept as low-normal $(0.35-1.125 \mu \mathrm{IU} / \mathrm{ml})$. All patients were re-evaluated at 3rd, 6th and 9th months and serum TSH, $\mathrm{FT}_{4}, \mathrm{FT}_{3}, \mathrm{Tg}-\mathrm{Ab}$ and TPO-Ab were measured. At the end of the study, in addition to serum thyroid hormone levels and thyroid autoantibodies, ultrasonographic and cytologic examinations of the thyroid gland and lymphocyte subpopulations from peripheral blood were repeated.

Two patients from each group were excluded from the study because two became pregnant, one had developed thymic carcinoma and one was lost to follow-up.
Twenty-nine patients completed 15 months of followup period. This study was approved as Thesis in Internal Medicine by our institution.

\section{Thyroid hormone measurements}

After 12 hours of fasting, blood samples were taken from antecubital vein. Thyroid hormone levels were measured by Architect (Abbott, USA) machine through Chemiluminiscent Microparticle Immunoassay (CMIA). Architect TSH Reagent Assay (N.6C52, intrassay variation $1.7-3.8 \%$, interassay variation 0.987 ), Architect Free $\mathrm{T}_{3}$ Reagent Assay (N.6C48, intrassay variation 2.3-5.0\%, interassay variation 0.957 ) and architect Free $\mathrm{T}_{4}$ Reagent Assay (N.6C50, intrassay variation 3.6$6.3 \%$, interassay variation 0.953 ) were used. Reference levels of our biochemistry laboratory were as follows: $\mathrm{FT}_{3}$ : 2.62-5.96 pmol/L, $\mathrm{FT}_{4}$ : $9.00-19.04 \mathrm{pmol} / \mathrm{L}$, TSH $0.35-4.95 \mu \mathrm{IU} / \mathrm{ml}$.

\section{Thyroid autoantibody measurements}

$\mathrm{Tg}-\mathrm{Ab}$ were measured with manual ELISA (Euroimmun, Germany, intraassay variation $3.1-7.3 \%$, interassay variation $6.8-7.8 \%$ ). Antibody levels up to 1.1 AU were accepted as normal. TPO-Ab were measured with TPO-Ab One Step RIA CT (Radioimmunometric Assay for the Quantitative Determination of Antithyroperoxidase Autoantibodies in Human Serum and Plasma, intraassay variation $6.6-7.9 \%$, interassay variation $6.7-12 \%$ ). Results over $30 \mathrm{IU} / \mathrm{ml}$ with gamma counter were considered abnormal.

\section{Thyroid ultrasonography}

Siemens Advanced Apparatus with $7.5 \mathrm{MHz}$ transducer was used. The total thyroid volume was calculated from the sum of the partial volumes of right and left lobe. The volume of each part was calculated by multiplication of length, thickness and width by 0.5 .

\section{Immunofluorescent staining}

Mononuclear cells were separated from blood with Ficoll gradient method. Fifty $\mu \mathrm{l}$ of mononuclear cell suspension was added to tubes containing $15 \mu \mathrm{l}$ of the appropriate monoclonal antibodies directly conjugated with fluorescein isothiocyanate (FITC) or phycoerythrin (PE) (Mouse Anti-Human Simultest Control IgG//gG ${ }_{1}$, 
CD3/CD19, CD3/CD16-56 CD4/CD8, Becton Dickinson, San Diego, CA). Samples were incubated at room temperature for 15 minutes in the dark. The remaining cells were washed with phosphate buffer saline (PBS) and $1 \%$ bovine seum albumin. Cells were resuspended in $4 \%$ paraformaldehyde and stored up to 24 hours at $4^{\circ} \mathrm{C}$ until they were analyzed by flow cytometry.

\section{Flow cytometry}

A FACS calibur flow cytometer (Becton Dickinson Immunocytometry Systems, San Diego, CA) equipped with a $15 \mathrm{~mW}$ air-cooled argon ion laser was used in the present study. An excitation wavelength of $488 \mathrm{~nm}$ and emission at $530 \mathrm{~nm}$ for FITC and $585 \mathrm{~nm}$ for PE were used. List mode data of two-color fluorescence, forward angle light scatter (FSC) and $90^{\circ}$ side scatter (SSC) were collected for 10,000 cells per specimen. The collected data were analyzed on a Macintosh Model G3 computer with CellQuest Software. Fluorescence data were collected on four-decade log scale. Calibration beads were used as an external standard at the beginning of each flow cytometric run to take care of any background staining. The relative numbers of lymphocyte subsets were expressed as percentage of the total lymphocyte population.

\section{Fine needle aspiration biopsy}

After application of $2 \%$ prilocaine hydrochloride, thyroid tissue was aspirated by $0.7 \times 32 \mathrm{~mm}$ needle by an experienced endocrinologist. On-site alcohol-fixed specimens were stained with Papanicolaou stain.

\section{Statistical analysis}

All results were expressed as means and standard deviations, medians and interquartile range. MannWhitney $U$ test, Wilcoxon test, Spearman rank correlation coefficient and Friedman tests were used.

\section{Results}

There was no statistical difference between age, sex, thyroid hormone, thyroid autoantibody levels, ultrasonographic and cytological findings or lymphocyte subpopulations between the two study groups. All the patients were positive for TPO-Ab, whereas $24.1 \%$ were negative for the Tg-Ab. No significant correlation was detected between antibody titers, thyroid volume and lymphocyte populations.

At the end of 15 months, while all the patients were receiving $\mathrm{LT}_{4}, \mathrm{FT}_{4}$ levels were significantly high and TSH levels were significantly low in Group $2(\mathrm{p}=$ 0.001 and $p<0.0001$ respectively, Fig. 1 and Fig. 2). There was no significant difference between $\mathrm{FT}_{3}$ levels. The average daily dose of $\mathrm{LT}_{4}$ ranged from 50 to $200 \mu \mathrm{g}$ (mean $80.39 \pm 11.48 \mathrm{SD}$ ). One patient in Group 1 developed sub-clinical hypothyroidism at the end of 9 months (TSH: $17.121 \mu \mathrm{IU} / \mathrm{ml}, \mathrm{FT}_{4}: 13.19$ $\mathrm{pmol} / \mathrm{L}$ and $\mathrm{FT}_{3}: 5.51 \mathrm{pmol} / \mathrm{L}$ ). Her thyroid hormone

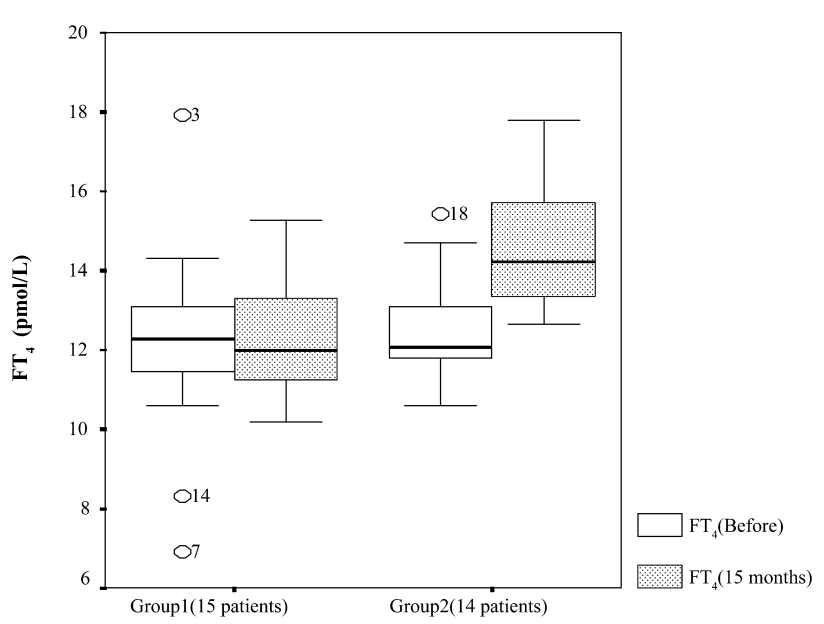

Fig. 1. $\mathrm{FT}_{4}(\mathrm{pmol} / \mathrm{L})$ levels before and after 15 months of follow-up. (Circles represent the outliers and numbers represent the case number)

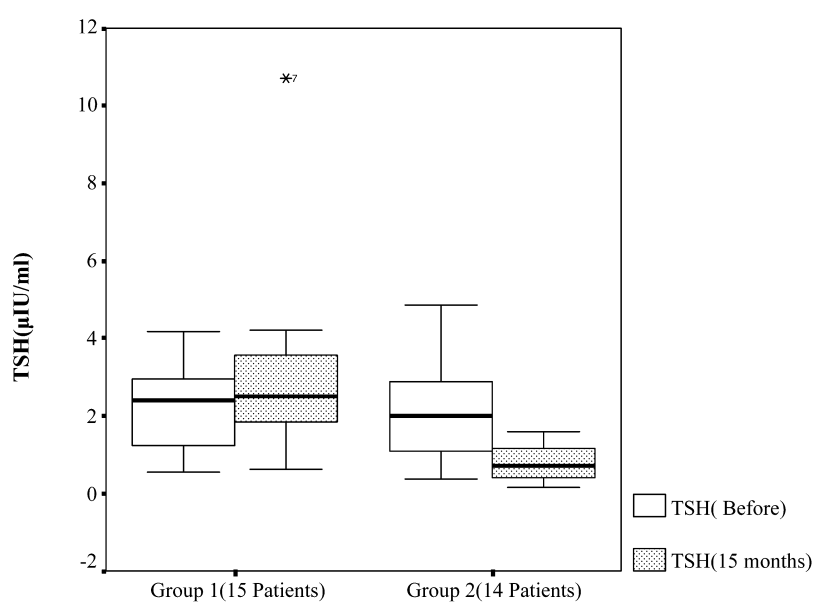

Fig. 2. TSH $(\mu \mathrm{IU} / \mathrm{ml})$ levels before and after 15 months of follow-up. (Asterisks represent extremes and numbers represent the case number) 
levels were TSH: $10.69 \mu \mathrm{IU} / \mathrm{ml} ; \mathrm{FT}_{3}: 5.64 \mathrm{pmol} / \mathrm{L}, \mathrm{FT}_{4}$ : $10.85 \mathrm{pmol} / \mathrm{L}$ at the end of the study. She was followed up closely and $\mathrm{LT}_{4}$ treatment was started at the end of the study. There were no adverse effects such as atrial fibrillation and osteoporosis in treatment group.

Although there seemed to be a significant decrease in $\mathrm{Tg}-\mathrm{Ab}$ levels in both groups during their first visit, it persisted only in Group 2 at the end of 15 months $(p=0.02$, Fig. 3). Likewise TPO-Ab levels decreased only in Group 2 at the end of the follow-up period $(p=0.013$, Table 1$)$. There was a significant correlation between the reduction of TSH levels and Tg-Ab levels $\left(\mathrm{R}_{\mathrm{s}}\right.$ : $\left.0.580, \mathrm{p}=0.03\right)$, but no such correlation was present between TSH and anti-TPO.

No changewas observed in absolute number of peripheral blood lymphocytes and percentages of $\mathrm{CD} 3$, CD4, CD19 or CD16/56 positive cells whereas the percentage of $\mathrm{CD}^{+}$cells were found to be increased in

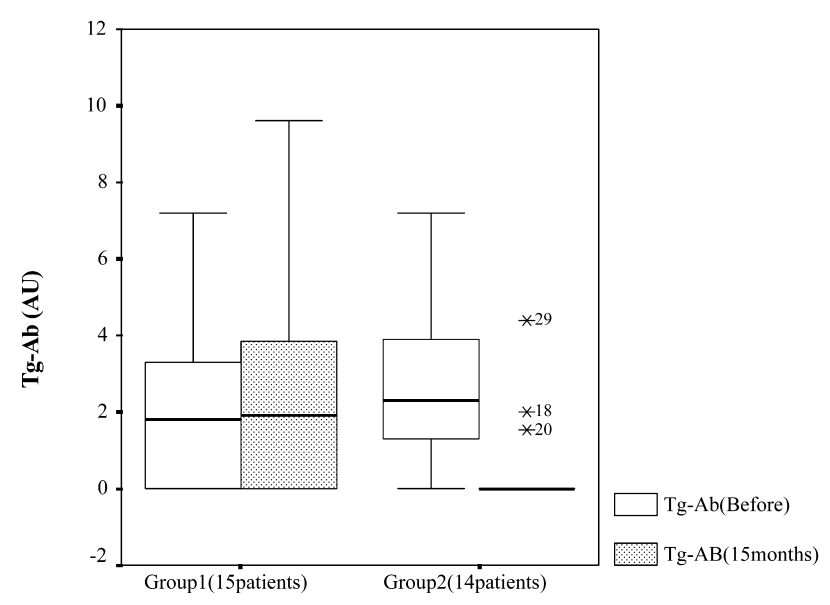

Fig. 3. $\mathrm{Tg}-\mathrm{Ab}(\mathrm{AU})$ before and after 15 months of follow-up. (Asterisks represent extremes and numbers represent the case number)

Table 1. Tg-Ab and TPO-Ab before and after 15 months of follow-up (Data expressed as median and interquartile range)

\begin{tabular}{lcccc}
\hline & \multicolumn{2}{c}{ Group 1 } & \multicolumn{2}{c}{ Group 2 } \\
\cline { 2 - 5 } & Before & $\begin{array}{c}\text { After } \\
15 \text { months }\end{array}$ & Before & $\begin{array}{c}\text { After } \\
15 \text { months }\end{array}$ \\
\hline$T g-A b(\mathrm{AU})$ & 1.8 & 1.9 & 2.3 & 0.0 \\
& $(3.4)$ & $(4.2)$ & $(2.68)$ & $(0.38)$ \\
$T P O-A b(\mathrm{IU} / \mathrm{ml})$ & 1304 & 686 & 2617 & 303 \\
& $(1550)$ & $(1992)$ & $(2435.5)$ & $(2920.9)$ \\
Thyroid Volume $(\mathrm{ml})$ & 9.5 & 12.2 & 13.2 & 11.7 \\
& $(7.9)$ & $(11.2)$ & $(9.9)$ & $(6.3)$ \\
\hline
\end{tabular}

both groups $(p=0.003$ and $p<0.0001$ for Groups 1 and 2 , respectively). There was no statistical difference between the amount of change in two groups regarding percentage and absolute number of $\mathrm{CD} 8^{+}$cells (Table 2).

We could not detect any change in either group regarding cytological findings. Thyroid volume increased in Group 1 and decreased in Group 2 at the end of the study $(p=0.008$ and $p=0.003$, respectively, Table 1, Fig. 4). A second FNAB was obtained from one patient from Group 2 because of uncertainity for lymphoma, and examination of intrathyroidal lymphocytes by flow cytometry revealed normal immunophenotypes.

\section{Discussion}

Hashimoto's thyroiditis is the most common autoimmune thyroid disorder characterized by presence of thyroid autoantibodies with a spectrum of clinical presentation changing from a large goiter to atrophy of

Table 2. $\mathrm{CD}^{+}$cells and CD4/CD8 ratio before and after 15 months (Data expressed as median and interquartile range)

\begin{tabular}{lcccc}
\hline & \multicolumn{2}{c}{ Group 1 } & \multicolumn{2}{c}{ Group 2 } \\
\cline { 2 - 5 } & Before & $\begin{array}{c}\text { After } \\
15 \text { months }\end{array}$ & Before & $\begin{array}{c}\text { After } \\
15 \text { months }\end{array}$ \\
\hline \multirow{2}{*}{ CD8 $8^{+}$Cells (\%) } & 25 & 32 & 22 & 32 \\
& $(8)$ & $(12)$ & $(14.50)$ & $(12.25)$ \\
CD4/CD8 Ratio & 1.5 & 1.3 & 1.95 & 1.3 \\
& $(0.6)$ & $(0.6)$ & $(1.62)$ & $(0.78)$ \\
\hline
\end{tabular}

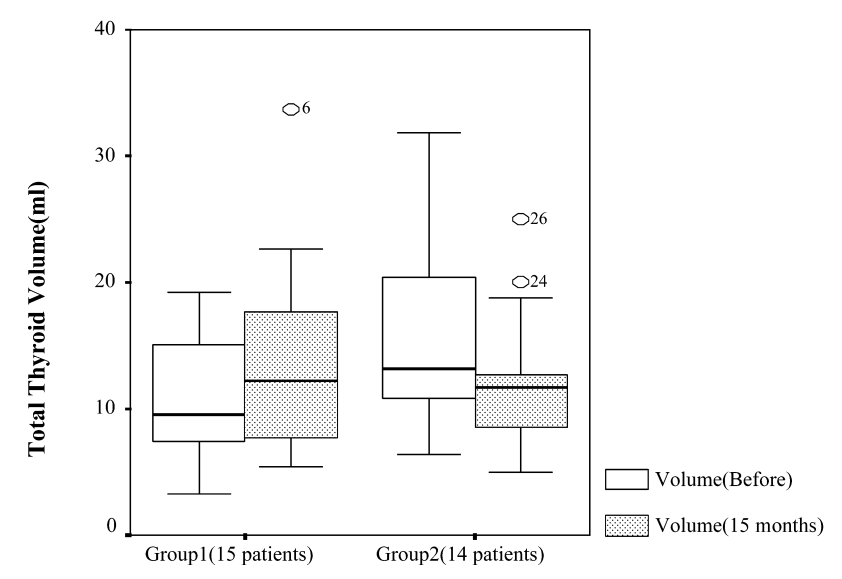

Fig. 4. Total thyroid volumes $(\mathrm{ml})$ before and after 15 months of follow-up. (Circles represent the outliers numbers represent the case number) 
the gland, hyperthyroidism to hypothyroidism [1, 2]. Although involvement of the immune system in the pathogenesis of the disease is well-known, the triggering impulse or the modulating factors on the disease process still need to be determined.

It is not yet clearly understood whether the typical autoantibodies present in the serum of the Hashimoto's thyroiditis patients play a direct role in the pathogenesis of disease or appear as a response to ongoing inflammatory reaction [23, 24]. A possible inhibitory effect of TPO-Ab on thyroid peroxidase enzyme is considered but its effect is probably indirect [25-27]. Many authors have reported that TPO-Ab has a correlation with the amount of lymphocytic infiltration and disease activity, Kasagi et al., however, claimed $\mathrm{Tg}-\mathrm{Ab}$ to be the critical determinant of the pathogenesis [2830]. All patients in this study have TPO-Ab in their serum but $24.1 \%$ of the patients were negative for $\mathrm{Tg}-\mathrm{Ab}$. The results were consistent with other studies where cytological findings were compared with antibody levels [25, 31-33].

In our study, $\mathrm{LT}_{4}$ treatment significantly decreased both TPO-Ab and Tg-Ab levels after 15 months of therapy. This effect could either be due to a decrease in TSH levels which may indirectly decrease the magnitude of antigenic presentation or through a plausible direct modulatory effect of $\mathrm{LT}_{4}$ itself. Direct modulatory effects of $\mathrm{LT}_{4}$ have been supported by some studies which showed increased viability of skin grafts in mice, decreased primary antibody concentrations and inhibition of cellular immune response after L-thyroxine treatment [34].

$\mathrm{LT}_{4}$ has been shown to decrease the incidence of lymphocytic thyroiditis and the amount of lymphocyte infiltration in animal models $[9,15,35]$. Although $\mathrm{LT}_{4}$ treatment is mandatory in hypothyroid autoimmune thyroiditis patients, $\mathrm{LT}_{4}$ treatment which is shown to inhibit autoimmune process in animal models, is still controversial in euthyroid Hashimoto's disease patients where disease has not destroyed the thyroid gland enough to cause hypothyroidism [17]. Variable results regarding the effect of $\mathrm{LT}_{4}$ treatment on autoantibodies are reported. Although some authors report a decrease in $\mathrm{Tg}-\mathrm{Ab}$ and/or TPO-Ab levels, other studies are not confirmatory $[10,11,15,17,36]$. Most of the study groups included hypothyroid patients and the studies with euthyroid patients were limited with conflicting results $[14,15,37]$.
The immune mechanism in Hashimoto's thyroiditis has been shown to start with $\mathrm{CD}^{+}$cell activation followed by participation of $\mathrm{CD} 8^{+}$lymphocytes and $\mathrm{B}$ cells [3]. Neither the triggering stimulus nor the exact interactions of immune system have been determined. Several studies revealed varying results for percentages of T, B cells and also of natural killer cells obtained from peripheral blood and thyroid $[17,18,38$ 40]. We were able to demonstrate an increase in the percentage of $\mathrm{CD}^{+}$cells in both groups which was independent of $\mathrm{LT}_{4}$ therapy. As there was not a healthy control group in this study, it is not possible to explain the change in $\mathrm{CD}^{+}$cells simply as a normalization through suppression of disease activity or as a sign of increased cytotoxicity which becomes prominent as time progresses. Absence of intrathyroidal lymphocyte examination was a limitation of our study from this point of view. We were not able to demonstrate an effect of $\mathrm{LT}_{4}$ on this process.

Prophylactic thyroid hormone therapy decreased the size of thyroid volume whereas follow-up without treatment resulted in a larger thyroid tissue. The effect of $\mathrm{LT}_{4}$ treatment on goiter size is much clearer on hypothyroid patients but our study is one of the few studies which could demonstrate this effect in euthyroid patients even at doses which kept TSH at low-normal levels [13].

$\mathrm{LT}_{4}$ treatment at doses keeping $\mathrm{TSH}$ at low-normal levels appears to be effective not only in decreasing the autoantibody levels but also in the goiter size. Although this immunomodulating effect cannot be explained through any alterations in lymphocyte subpopulations (though $\mathrm{CD} 8^{+}$levels increased it was independent of $\mathrm{LT}_{4}$ treatment), there appears to be an inhibitory effect of $\mathrm{LT}_{4}$ treatment on the ongoing disease process in Hashimoto's thyroditis patients. Early treatment of euthyroid Hashimoto's thyroiditis patients with L-thyroxine may slow down not only the disease process itself but through its immune modulating events it may also affect the course of other autoimmune diseases which accompany. $\mathrm{LT}_{4}$ therapy could be used for these beneficial effects in patients with euthyroid Hashimoto's disease but we believe questions including selection of patients for treatment, duration and doses of treatment still need to be answered by conducting further prospective studies in patients with Hashimoto's thyroiditis. 


\section{References}

1. Hashimoto H (1912) Zur Kenntniss der lymphomatösen Veranderung der Schilddrüse (Struma lymphomatosa). Arch Klin Chir 97: 219-248.

2. Roitt IM, Doniach D, Campbell PN, Hudson RV (1956) Auto-antibodies in Hashimoto's disease (lymphadenoid goitre) Lancet 2: 820-821.

3. Pearce EN, Farwell MD, Braverman LE (2003) Thyroiditis. $N$ Eng J Med 348: 2646-2655.

4. Weetman AP (1992) Autoimmune thyroiditis: predisposition and pathogenesis. Clin Endocrinol 36: $307-$ 323.

5. Iwatani $\mathrm{Y}$, Amino $\mathrm{N}$, Kabutomori O, Tamaki $\mathrm{H}$, Aozasa M, Motoi S, Miyai K (1988) Effects of different sample preparations on enumeration of large granular lymphocytes (LGLs) and demonstration of sex difference of LGL. Am J Clin Pathol 90: 674-678.

6. Iwatani Y, Amino N, Tachi J, Kimura M, Ura I, Mori M, Miyai K, Nasu M, Tanizawa O (1988) Changes of lymphocyte subsets in normal pregnant and postpartum women: postpartum increase of NK/K (leu7) cells. $\mathrm{Am}$ J Reprod Immunol Microbiol 18: 52-55.

7. Routhier G, Epstein O, Janossy G, Thomas HC, Sherlock S, Kung PC, Goldstein G (1980) Effects of cyclosporin A on suppressor and inducer $\mathrm{T}$ lymphocytes in primary biliary cirrhosis. Lancet 2: $1223-$ 1226.

8. Levi F, Canon C, Blum JP, Reinberg A, Mathe G (1983) Large amplitude circadian rhythm in helper: suppressor ratio of peripheral blood lymphocytes. Lancet 2: 462-463.

9. Schumm-Draeger PM, Wenzel BE (1996) In vivo models in thyroid research. Exp Clin Endocr Diabetes 104 (Supp 3): 1-63.

10. Rieu M, Richard A, Rosilio M, Laplanche S, Ropion V, Fombeur JP, Berrod JL (1994) Effects of thyroid status on thyroid autoimmunity expression in euthyroid and hypothyroid patients with Hashimoto thyroiditis. Clin Endocrinol (Oxf) 40: 529-535.

11. Romaldini JH, Biancalana MM, Figueiredo DI, Farah CS, Mathias PC (1996) Effect of L-thyroxine administration on antithyroid antibody levels, lipid profile and thyroid volume in patients with Hashimoto's disease. Thyroid 6: 183-188.

12. Hayashi Y, Tamai H, Fukata S, Hirota Y, Katayama S, Kuma K, Kumagai LF, Nagataki S (1985) A long term clinical, immunological and histological follow-up: study of patients with goitrous chronic lymphocytic thyroiditis. J Clin Endocrinol Metab 61: 1172-1178.

13. Papapetrou PD, MacSween RN, Lazarus JH, Harden RM (1972) Long-term treatment of Hashimoto's thyroiditis with thyroxine. Lancet 2: 1045-1048.

14. Padberg S, Heller K, Usadel KH, Schumm-Draeger PM (2001) One year prophylactic treatment of euthy- roid Hashimoto's thyroiditis patients with levothyroxine: Is there a benefit? Thyroid 11: 249-255.

15. Iwatani Y, Amino N, Hidaka Y, Kaneda J, Ichihara K, Tamaki H, Matsuzuka F, Fukata S, Kuma K, Miyaki K (1992) Decreases in $\alpha \beta$ T cell receptor negative T cells and $\mathrm{CD}^{+}$and increase in $\mathrm{CD} 4^{+} \mathrm{CD}^{+}$cells in active Hashimoto's disease and subacute thyroiditis. Clin Exp Immunol 87: 444-449.

16. Wenzel BE, Chow A, Baur R, Schleusener H, Wall JR (1998) Natural killer cell activity in patients with Graves' disease and Hashimoto's thyroiditis. Thyroid 8: 1019-1022.

17. MacKenzie WA, Schwartz AE, Friedman EW, Davies TF (1987) Intrathyroidal $T$ cell clones from patients with autoimmune thyroid disease. J Clin Endocrinol Metab 64: 818-824.

18. Schumm-Draeger P-M, Padberg S, Heller K (1999) Prophylactic levothyroxine therapy in patients with Hashimoto's thyroiditis. Exp Clin Endocrinol Diabetes Supp (3): 84-87.

19. Chiovata L, Marcocci C, Mariotti S, Mori A, Pinchera (1986) A L-thyroxine therapy induces a fall of thyroid microsomal and thyroglobulin antibodies in idiopathic myxedema and in hypothyroid but not in euthyroid Hashimoto's thyroidits. J Endocrinol Invest 9: 299305.

20. Gessl A, Wilfing A, Agis H, Steiner G, Czernin S, Boltz-Nitulescu G, Vierhapper H, Waldhausl W (1995) Activated naive $\mathrm{CD}^{+}$peripheral blood T cells in autoimmune thyroid disease. Thyroid 5: 117-125.

21. Fujikawa M Okamura K,Sato K, Mizokami T, Tanabe S, Ikenoue H, Okamura S, Ohta M, Fujishima M (1998) Usefulness of surface phenotype study of intrathyroidal lmphocytes obtained by fine needle aspiration cytology in autoimmune thyroid disease and malignant lymphoma of the thyroid. Clin Endocrinol (Oxf) 49: 191-196.

22. Hidaka Y, Amino N, Iwatani Y, Kaneda T, Nasu M, Mitsuda N, Tanizawa O, Miyai K (1992) Increase in peripheral natural killer cell activity in patients with autoimmune thyroid disease. Autoimmunity 11: 239246.

23. Tomer Y (1997) Antithyroglobulin autoantibodies in autoimmune thyroid diseases : Cross-reactive or pathogenic? Clin Immunol Immunopathol 82: 3-11.

24. McIntosh RS, Asghar MS, Weetman AP (1997) The antibody response in human autoimmune thyroid disease. Clin Sci 92: 529-541.

25. Dayan CM, Daniels GH (1996) Chronic autoimmune thyroiditis. N Eng J Med 335: 99-107.

26. Scherbaum WA, Paschke R (1995) Significance of thyroid antibodies for diagnosis and follow-up of thyroid diseases. Internist (Berl) 36: 303-309. 
27. Heufelder AE, Hofbauer LC (1995) Die Thyreoiditiden Aktueller Stand der Pathogenese, Diagnostik und Therapie. Dt Ärsteblatt 95: 566-576.

28. Engler H, Riesen WF, Keller B (1992) Diagnostic value of autoantibodies against microsomal thyroid peroxidase (antiTPO). Schweiz Med Wochenschr 122: 1976-1980.

29. Nordyke RA, Gilbert FI Jr, Miyamoto LA, Fleury KA (1993) The superiority of antimicrosomal over antithyroglobulin antibodies for detecting Hashimoto's thyroiditis. Arch Inter Med 153: 862-865.

30. Kasagi K, KousakaT, Higuchi K, Iida Y, Misaki T, Alam MS, Miyamoto S, Yamabe H, Konishi J (1996) Clinical significance of measurement of antithyroidal antibodies in the diagnosis of Hashimoto's thyroiditis: comparison with histological findings. Thyroid 6: 445450.

31. Singer PA (1991) Thyroiditis acute, subacute and chronic. Med Clin North Am 75: 61-77.

32. DeGroot LJ, Quintans J (1990) The cause of autoimmune thyroid disease. Endocr Rev 6: 445-450.

33. Rapoport B (1991) Pathophysiology of Hashimoto's thyroiditis and hypothyroidism. Annu Rev Med 42: 9196.

34. Gupta MK, Chiang T, Deodhar SD (1983) Effect of thyroxine on immune response in CD 57B1/6J mice. Acta Endocrinol 103: 76-80.

35. Banovac K, Ghandur-Mnaymneh L, Zakarija M,
Rabinovitch A, McKenzie JM (1988) The effect of Thyroxine on spontaneous thyroiditis in $\mathrm{BB} / \mathrm{W}$ rats. Int Arch Allergy Appl Immunol 87: 301-305.

36. Jansson R, Karlsson A, Dahlberg PA (1985) Thyroxine, methimazole and thyroid microsomal autoantibody titers in hypothyroid Hashimoto's thyroiditis. $\mathrm{Br}$ Med J 290: 11-12.

37. Chiovata L, Marcocci C, Mariotti S, Mori A, Pinchera A (1986) L-thyroxine therapy induces a fall of thyroid microsomal and thyroglobulin antibodies in idiopathic myxedema and in hypothyroid but not in euthyroid Hashimoto's thyroiditis. J Endocrinol Invest 9: 299305 .

38. MacKenzie WA, Schwartz AE, Friedman EW, Davies TF (1987) Intrathyroidal $T$ cell clones from patients with autoimmune thyroid disease. J Clin Endocrinol Metab 64: 818-824.

39. Gessl A, Wilfing A, Agis H, Steiner G, Czernin S, Boltz-Nitulescu G, Vierhapper H, Waldhausl W (1995) Activated naive $\mathrm{CD}^{+}$peripheral blood $\mathrm{T}$ cells in autoimmune thyroid disease. Thyroid 5: 117-125.

40. Fujikawa M, Okamura K, Sato K, Mizokami T, Tanabe S, Ikenoue H, Okamura S, Ohta M, Fujishima M (1998) Usefulness of surface phenotype study of intrathyroidal lmphocytes obtained by fine needle aspiration cytology in autoimmune thyroid disease and malignant lymphoma of the thyroid. Clin Endocrinol (Oxf) 49: 191-196. 